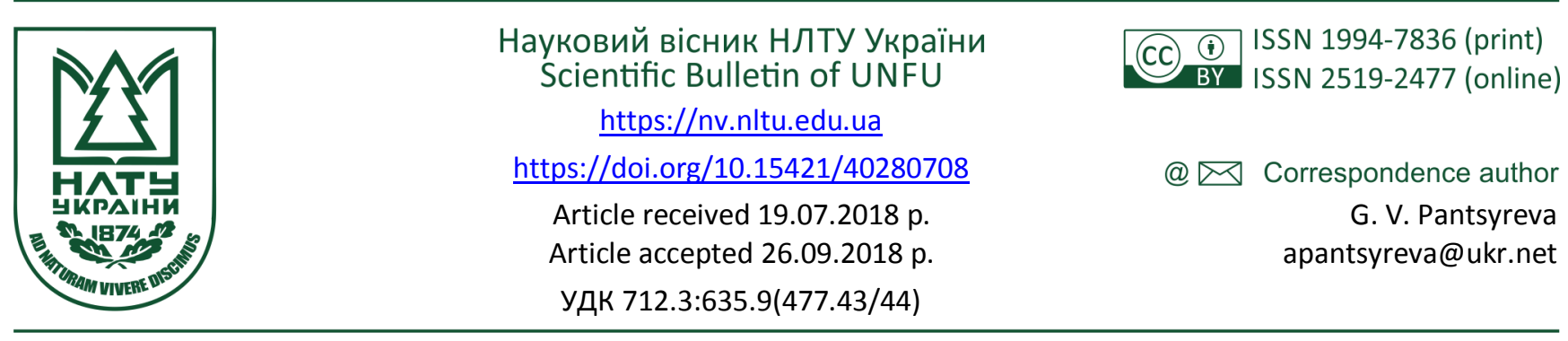

В. А. Мазур, В. М. Прокопчук, Г. В. Панцирева

Вінницький національний аграрний університет, м. Вінниця, Украйна

\title{
ПЕРВИННЕ ІНТРОДУКЦІЙНЕ ОЦІНЮВАННЯ ДЕКОРАТИВНИХ ВИДІВ РОДУ LUPINUS В УМОВАХ ПОДІЛЛЯ
}

Наведено результати первинного інтродукційного випробування квітниково-декоративних рослин, що належать до представників роду Lupinus L. в умовах Поділля. Проаналізовано видовий склад роду Lupinus та визначено перспективність їх використання для озеленення різних об'єктів зони Поділля. Для диференціації рослин відповідно до сфери їх можливого використання наведено морфометричні показники найперспективніших представників цього роду. Встановлено, що всі досліджувані види викликають інтерес як потенційно цінні об'єкти для збагачення асортименту вітчизняних декоративних рослин та є перспективними для поліпшення стану парків, скверів, садків зони Поділля. Враховуючи високі декоративні якості цих видів та широкі можливості їх застосування, квітниково-декоративні рослини представників роду Lupinus L мають важливе значення для садівництва та для поповнення асортименту декоративних культур нашої держави. З'ясовано, що природні можливості представників роду Lupinus, пластичність до зміни їх життєвої форми, висока якість за сукупністю ознак, що визначають їх декоративність, характеризує досліджувані рослини як джерело для інтродукції і збагачення асортименту декоративних культур в Україні. Отже, інтродукція представників роду Lupinus для озеленення дасть змогу значно розширити асортимент декоративно цінних рослин та збагатити культивовану флору зони Поділля та України загалом.

Ключові слова: інтродукція; люпин; морфометричні показники; природний ареал; біоморфологічні особливості.

Вступ. Питання збагачення та оновлення асортименту декоративних рослин завжди є актуальним для будь-якої країни світу. Запровадження у широку виробничу практику нових перспективних видів і форм рослин, відібраних унаслідок багаторічних інтродукційних досліджень, є одним з основних завдань інтродукції. Кількість видів, форм, сортів інтродукованих рослин роду Lupinus (Fabaceae), які поширені в Україні, обмежена. Деякі з них є надбанням тільки інтродукційних центрів і рідко використовуються в озелененні через відсутність даних з біологічних особливостей і ефективних методів розмноження їх в умовах культури (Bylov, 1978).

У сучасних умовах для України актуальність цих питань підсилюється ще й тим, що асортимент декоративних культур, які використовують у нашій країні, наразі ще бідний. Інтродукція представників роду Lupinus для озеленення дасть змогу значно розширити асортимент декоративно цінних рослин та збагатити культивовану флору України.

Враховуючи різноманіття декоративних видів представників роду Lupinus за призначенням, кольоровою гамою, габітусом, формою декоративних елементів, а також їх значну кількість у культурі розвинених країн світу, беручи до уваги факт їх незначної кількості в цій галузі нашої держави, питання визначення можливостей та шляхів використання потенціалу цих рослин для збагачення культигенної фракції флори є важливим як 3 наукової, так і практичної точок зору. Його вирішення стане істотним кроком на шляху підвищення якості вітчизняного асортименту декоративних рослин (Laptiev, 2001).

Аналіз останніх досліджень і публікацій. Рід Lupinus нараховує близько 200 видів, що зростають у Північній Америці та Середземномор'ї. Багаторічні кореневищні трав'яні рослини, рідше напівчагарники.

3 багаторічних видів у культурі частіше трапляються люпин деревоподібний (L. arboreus Sims.) - багаторічна рослина, 1,5 м заввишки, з білими і жовтими кольорами, квітне в липні-серпні. 31826 р. у культурі люпин багатолистий (L. polyphyllus Lindl.) з численними садовими формами і сортами гібридного походження, з квітками як однотонними, так і двокольоровими: 'Abendglut', 'Albus', 'Apricot', 'Carmineus', 'Neue Spielarten', 'Prinzess Juliana', 'Roseus', 'Rubinkonig' (Zhurnal, 2018).

Довгий час селекцію люпину здійснював англійський селекціонер Джордж Рассел. В Україні поширеними стали одноколірні сортопопуляції, виділені з гібридів Рассела: Бург Фройлен, Кронлойхтер, Шлоссфрау, Майн Шлосс, Еделькбане, Кастеллян. Окрім одноколір-

\section{Інформація про авторів:}

Мазур Віктор Анатолійович, канд. с.-г. наук, доцент, ректор. Email: mazur@vsau.vin.ua

Прокопчук Валентина Мар'янівна, канд. біол. наук, доцент, завідувач кафедри садово-паркового господарства, садівництва та виноградарства. Email: prokopchuk@vsau.vin.ua

Панцирева Ганна Віталіївна, канд. с.-г. наук, ст. викладач, кафедра садово-паркового господарства, садівництва та виноградарства. Email: apantsyreva@ukr.net

Цитування за ДСту: Мазур В. А., Прокопчук В. М., Панцирева Г. В. Первинне інтродукційне оцінювання декоративних видів роду lupinus в умовах Поділля. Науковий вісник НлтУ України. 2018, т. 28, № 7. С. 40-43.

Citation APA: Mazur, V. A., Prokopchuk, V. M., \& Pantsyreva, G. V. (2018). Primary introduction assessment of decorative species of the lupinus generation in Podillya. Scientific Bulletin of UNFU, 28(7), 40-43. https://doi.org/10.15421/40280708 
них, на сьогодні існують унікальні різноколірні сортопопуляції зі широким спектром тонів і відтінків від білого до фіолетового: Абенглют, Сплендід. Серед новинок дуже ефектна низькоросла сортопопуляція: Мінарет. Люпин Лулу - найскороспіліша суміш сортів серед багаторічного люпину (Ishchuk et al., 2014; Atkins, 2002).

Люпин висаджують в одиночних і групових насадженнях 3 іншими багаторічниками у міксбордерах, групами на газоні. Ефектні в букетах, але стоять недовго. Люпини - рослини другого ряду. Добре поєднуються у змішаних насадженнях із хостами, півниками, ромашками, лілеями, дельфініями, астильбами та ін. (Ishchuk et al., 2014; Sowling, 1994; Kormilitcyn, 1966). Враховуючи високі декоративні якості цих видів та широкі можливості їх застосування, ці рослини мають значний інтерес для садівництва нашої країни та для поповнення асортименту квітниково-декоративних культур (Nemchenko, 2001).

Метою $i$ завданням є дослідження біоморфологічних особливостей 11 видів роду Lupinus (L. cosentinii Guss., L. pilosus, L. athlanticus, L. digitatus, L. hispanicus, L. princei, L. albicaulis Douglas, L. arboreus Sims, L. perennis L., L. nootkatensis Donn ex Sims.) та визначення перспективності їх вирощування в умовах зони Поділля.

Матеріали та методи дослідження. Дослідження проводили впродовж 2015-2017 рр. на базі дослідних ділянках біостаціонару Вінницького національного аграрного університету. Грунтово-кліматичні умови зони дослідження сприятливі для вирощування перерахованих видів роду Lupinus.

Первинне інтродукційне випробування і відповідне оцінювання досліджуваних квітниково-декоративних видів здійснювали за методикою, яку розробив В. Н. Билов (Bylov, 1978).

Результати дослідження та їх обговорення. 3 безлічі видів представників роду Lupinus (за класифікацією різних авторів від декількох десятків до декількох сотень) у більшості країн світу, зокрема й Україні, куль- тивують лише чотири: люпин вузьколистий (L. angustifolius L.), люпин жовтий (L. luteus L.), люпин білий (L. albus L.), люпин мінливий (L. mutabilis L.). Створені малоалкалоїдні форми багаторічного люпину багатолистого (L. polyphyllus Lindl.) мають попит, однак ще не створено насіннєвого фонду. На основі цього виду отримано багато сортів (переважно закордонної селекції), які використовують як декоративну культуру.

На відміну від інших культур, багато видів люпину введено в культуру зовсім недавно: вузьколистий і жовтий - в середині XIX ст., інші види - у XX ст. Тільки два види люпину - мінливий і білий - давні культурні рослини, культивуються впродовж тисячоліть. Так, сучасні культурні форми цих видів за морфологічними особливостями, забарвленням і розміром відрізняються від стародавніх представників (Kormilitcyn, 1966). Культивовані в недавні часи види люпину також відрізняються від тих, що зростають у дикій природі, за габітусом рослини, абортивністю квіток і бобів, розміром та якістю насіння, стійкістю до біотичних і абіотичних факторів (Sowling, 1994).

Враховуючи, що найбільше видове різноманіття 3 переважним числом багаторічних видів люпину зосереджено в Новому Світі й невелика кількість - у Середземномор'ї (Старий Світ), серед дикорослих видів роду Lupinus є чимало перспективних форм, придатних для введення в культуру в Україні. Агрокліматичні умови нашої країни, а також успішна інтродукція представників диких видів люпину у віддалені від центрів їх походження регіони, є підставою для введення їх у зону Поділля (Atkins, 2002).

Розглянемо біологічні та декоративні характеристики видів, деякі з яких вже частково окультурено та такі, що трапляються тільки в дикій природі. Проаналізувавши праці вітчизняних та світових науковців, таких як В. Ф. Камінський, В. Ф. Петриченко, К. Smith, J. G. Wilson, M. W. Sweetingham, а також австралійського монографа роду Lupinus J. S. Gladstones ми описали природні ареали представників роду Lupinus (табл. 1).

Табл. 1. Природні ареали представників роду Lupinus та показники мінімальних температур їх природних місцезростань

\begin{tabular}{|c|c|c|c|}
\hline $\begin{array}{l}\text { № } \\
\text { 3/ח }\end{array}$ & Назва виду & Природний ареал виду & $\begin{array}{c}\text { Мінімальна тем- } \\
\text { пература, }{ }^{\circ} \mathrm{C}\end{array}$ \\
\hline 1 & Люпин Косентина (L. cosentinii Guss.) & Західна Австралія & $-6,7-10,8$ \\
\hline 2 & Люпин волосистий (L. pilosus) & $\begin{array}{l}\text { Греція, Туреччина, Ліван, Сирія, Ізраїль, Західна } \\
\text { Йорданія }\end{array}$ & $-7,8-12,5$ \\
\hline 3 & Люпин атлантичний (L. athlanticus) & Австралія & $-6,6-16,8$ \\
\hline 4 & Люпин пальчастий (L. digitatus) & Єгипет & $-1,3-5,7$ \\
\hline 5 & Люпин іспанський (L. hispanicus) & Північно-західна Іспанія, Північна Португалія & $-12,9-17,6$ \\
\hline 6 & Люпин сомалійський (L. princei) & гори Кенії та Танзанії, Південна Ефіопія & $-12,7-19,8$ \\
\hline 7 & |Люпин білостебловий (L. albicaulis Douglas) & Канада & $-4,9-12,2$ \\
\hline 8 & Люпин витончений (L. ornatus Douglas) & Перу & $-7,0-12,2$ \\
\hline 9 & Люпин деревовидний (L. arboreus Sims.) & США, Канада, Ірландія, Великобританія, Зеландія & $-3,9-12,3$ \\
\hline 10 & Люпин багаторічний (L. perennis L.) & США, Канада & $-5,7-12,3$ \\
\hline 11 & (Люпин нутканський (L. nootkatensis Donn ex Sims.) & Канада, Шотландія, Норвегія, Швеція, Камчатка & $-5,6-30,9$ \\
\hline
\end{tabular}

Примітка: інформацію наведено для роду, види якого використовують у декоративному садівництві.

За даними літературних джерел усі види люпину на цей материк завезли перші поселенці з Америки. Наприкінці ХХ ст. поряд з традиційними у світі видами люпину (вузьколистим, білим, жовтим і мінливим) в Австралії селекцією було створено нові види з декоративними якостями L. cosentinii Guss., L. athlanticus Gladst. i L. pilosus Murr, які стали невід'ємною частиною австралійських наукових досліджень.

Проаналізувавши літературні дані, окрім перерахованих, на погляд австралійських учених, для введення в культуру перспективні ще такі декоративні види: $L$. princei Harms., L. digitatus Forsk. i L. hispanicus Boiss. et Reut (Zhurnal, 2018; Entciklopediia, 2018). 3 незначного досвіду вирощування декоративних рослин цього роду, більшість із них в умовах країн Свропи, а також США та Канади здатні добре розвиватись, переносити холодний період року, цвісти та плодоносити. Проте на сьогодні недостатньо вивчено питання щодо характеристики зазначених вище видів. За результатами досліджень наведено основні морфометричні показники (ви- 
сота рослин, забарвлення квітки та строки цвітіння) найбільш перспективних декоративно-цінних представників роду Lupinus (табл. 2).

Отже, природні можливості представників роду $L u$ pinus, пластичність до зміни їх життєвої форми, висока якість за сукупністю ознак, що визначають їх декора- тивність, характеризує ці рослини як джерело для інтродукції і збагачення асортименту декоративних культур в Україні. Узагальнені рекомендації щодо використання різних видів роду Lupinus в озелененні з урахуванням їх біоморфологічних особливостей наведено в табл. 3.

Табл. 2. Морфометричні показники, забарвлення квітки та строки цвітіння основних декоративно цінних представників роду Lupinus

\begin{tabular}{|c|c|c|c|c|}
\hline $\begin{array}{l}\text { № } \\
\text { 3/ח }\end{array}$ & Назва виду & $\begin{array}{c}\text { Висота рослин, } \\
\text { см }\end{array}$ & Строки цвітіння & Забарвлення квітки \\
\hline 1 & Люпин Косентина (L. cosentinii Guss.) & $70-120$ & липень-серпень & біло-рожеве \\
\hline 2 & Люпин волосистий (L. pilosus) & $30-80$ & травень-липень & червоно-коричневе, рожевий \\
\hline 3 & Люпин атлантичний (L. athlanticus) & $45-60$ & серпень-вересень & рожеве, коричневий \\
\hline 4 & Люпин пальчастий (L. digitatus) & $15-40$ & червень-липень & червоно-коричневе, 3 плямами \\
\hline 5 & Люпин іспанський (L. hispanicus) & $80-90$ & серпень-вересень & жовте \\
\hline 6 & Люпин сомалійський (L. princei) & $50-70$ & липень-серпень & світло-фіолетове, рожеве \\
\hline 7 & Люпин білостебловий (L. albicaulis Douglas.) & $40-70$ & травень-липень & біле \\
\hline 8 & Люпин витончений (L. ornatus Douglas.) & $40-80$ & серпень-вересень & яскраво червоне, фіолетове \\
\hline 9 & Люпин деревовидний (L. arboreus Sims.) & $150-160$ & травень-липень & жовте, голубе \\
\hline 10 & Люпин багаторічний (L. perennis L.) & $100-110$ & серпень-вересень & біле, жовте, рожеве \\
\hline 11 & Люпин нутканський (L. nootkatensis Donn ex Sims.) & $40-90$ & червень-липень & сине, біле, голубе \\
\hline
\end{tabular}

Примітка: інформацію наведено для роду, види якого використовують у декоративному садівництві.

Табл. 3. Біоморфологічні особливості та рекомендації з використання основних декоративно цінних представників роду Lupinus

\begin{tabular}{|c|l|c|c|c|}
\hline $\begin{array}{c}\text { № } \\
3 / \Pi\end{array}$ & \multicolumn{1}{|c|}{ Назва виду } & $\begin{array}{c}\text { Життєва } \\
\text { форма }\end{array}$ & Тип вегетації & Рекомендації з використання \\
\hline 1 & Люпин Косентина (L. cosentinii Guss.) & однорічник & літньозелений & групи, міксбордер, клумби \\
\hline 2 & Люпин волосистий (L. pilosus) & однорічник & літньозелений & $\begin{array}{c}\text { на зріз, групи, міксбордер, рабатки, } \\
\text { клумби }\end{array}$ \\
\hline 3 & Люпин атлантичний (L. athlanticus) & однорічник & $\begin{array}{c}\text { літньозимозе- } \\
\text { лений }\end{array}$ & клумби, бордюр, рабатки, міксбордер \\
\hline 4 & Люпин пальчастий (L. digitatus) & однорічник & літньозелений & $\begin{array}{c}\text { клумби, рабатки, бордюр, } \\
\text { підпірні стінки, альпійські гірки }\end{array}$ \\
\hline 5 & Люпин іспанський (L. hispanicus) & однорічник & літньозелений & $\begin{array}{c}\text { клумби, рабатки, бордюр, } \\
\text { підпірні стінки }\end{array}$ \\
\hline 6 & Люпин сомалійський (L. princei) & однорічник & літньозелений & солітери на фоні газону, групи, клумби \\
\hline 7 & Люпин білостебловий (L. albicaulis Douglas.) & багаторічник & літньозелений & клумби, рабатки, групи \\
\hline 8 & Люпин витончений (L. ornatus Douglas.) & багаторічник & літньозелений & клумби, бордюр, підпірні стінки, групи \\
\hline 9 & Люпин деревовидний (L. arboreus Sims.) & багаторічник & літньозелений & рабатки, групи, солітери, клумби \\
\hline 10 & Люпин багаторічний (L. perennis L.) & багаторічник & літньозелений & групи, клумби, солітери \\
\hline 11 & Люпин нутканський (L. nootkatensis Donn ex Sims. $)$ & однорічник & літньозелений & групи, клумби, бордюр \\
\hline
\end{tabular}

Примітка: інформацію наведено для роду, види якого використовують у декоративному садівництві.

3 практичної точки зору, всі досліджувані види викликають інтерес як потенційно цінні об'єкти для збагачення асортименту декоративних рослин України та $є$ перспективними для поліпшення стану парків, скверів, садків зони Поділля. Саме збагачення видової різноманітності декоративних культур інтродукованими видами роду Люпину, розширення варіантів простих і комплексних садових композицій з їх участю, більш рівномірне їх розміщення в межах населених пунктів, значно наблизить оформлення населених міст України до рівня кращих світових зразків.

Висновки. Усі види роду Lupinus, що пройшли первинне інтродукційне випробування за комплексом показників, які визначають їх декоративність та господарсько-біологічні якості, оцінено як добре адаптовані до едафокліматичних умов Поділля і рекомендовано як об'єкти для збагачення асортименту рослин для озеленення колекційних та експозиційних фондів.

\section{Перелік використаних джерел}

Atkins, C. A. (2002). Phenotypic diversity among annual lupins used for crops or having cropping potential. Internat. Conf. on Legumes Genomic and Genetics, Abstracts, 4, 123-140.
Bylov, V. N. (1978). Osnovy sravnitelnoi sortootcenki dekorativnykh rastenii (Introduktciia i selektciia tcvetochno-dekorativnykh rastenii). Moscow: Nauka. 32 p. [In Russian].

Entciklopediia. (2018). Entciklopediia sadovykh rastenii. Retrieved from: www.websad.ru. [In Russian].

Ishchuk, L. P., Oleshko, O. H., Cherniak, V. M., \& Kozak, L. A. (2014). Kvitnykarstvo, (pp. 56-57). Bila Tserkva. 360 p. [In Ukrainian].

Kormilitcyn, A. M. (1966). Nabliudeniia i nauchnaia dokumentatciia $v$ arboretume GNBS. Yalta. 8 p. [In Russian].

Kormilitcyn, A. M. (1966). Ukazanii po fenologicheskim nabliudeniiam i biometricheskim izmereniiam v arboretume GNBS. Yalta. 16 p. [In Russian].

Laptiev, O. O. (2001). Introduktsiia ta aklimatyzatsiia roslyn z osnovamy ozelenennia. Kyiv: Fitosotsiotsentr. 109 p. [In Ukrainian].

Nemchenko, E. P. (2001). Mnogoletnie tcvety v sadu. Moscow: Fyton. 273 p. [In Russian].

Sowling, W. A. (1994). Plant breeding for stable agriculture: Presidential Address, (pp. 183-184). Western Australia, 340 p.

Sowling, W. A. (1994). Plant breeding for stable agriculture: Presidential Address, (pp. 183-184). Western Australia, 256 p.

Zhurnal. (2018). Zhurnal "Landshaftnyi dizain plius". Retrieved from: www.garden.part1.rar. [In Russian]. 


\section{ПЕРВИЧНАЯ ИНТРОДУКЦИОННАЯ ОЦЕНКА ДЕКОРАТИВНЫХ ВИДОВ РОДА LUPINUS В УСЛОВИЯХ ПОДОЛЬЯ}

Приведены результаты первичного интродукционного испытания цветочно-декоративных растений, принадлежащих к представителям рода Lupinus L. в условиях Подолья. Проведен анализ видового состава рода Lupinus и определена перспективность их использования для озеленения различных объектов зоны Подолья. С целью дифференциации растений в соответствии со сферой их возможного использования приведены морфометрические показатели наиболее перспективных представителей данного рода. Установлено, что все исследуемые виды вызывают интерес как потенциально ценные объекты для обогащения ассортимента отечественных декоративных растений и являются перспективными для улучшения состояния парков, скверов, садов зоны Подолья. Учитывая высокие декоративные качества данных видов и широкие возможности их применения, цветочно-декоративные растения представителей рода Lupinus L. имеют важное значение для садоводства и для пополнения ассортимента декоративных культур нашего государства. Установлено, что природные возможности представителей рода Lupinus, пластичность к изменению их жизненной формы, высокое качество по совокупности признаков, определяющих их декоративность, характеризует исследуемые растения как источник для интродукции и обогащения ассортимента декоративных культур в Украине. Итак, интродукция представителей рода Lupinus для озеленения даст возможность значительно расширить ассортимент декоративно ценных растений и обогатить культивируемую флору зоны Подолья и Украины в целом.

Ключевые слова: интродукция; люпин; морфометрические показатели; природный ареал; биоморфологические особенности.

V. A. Mazur, V. M. Prokopchuk, G. V. Pantsyreva

Vinnytsia National Agrarian University, Vinnytsia, Ukraine

\section{PRIMARY INTRODUCTION ASSESSMENT OF DECORATIVE SPECIES OF THE LUPINUS GENERATION IN PODILLYA}

Introduction of a wide industrial practice of new promising species and forms of plants, selected as a result of many years of introductory research, remains one of the main tasks of introduction. The results of the initial introductory test of flowering-ornamental plants of the genus Lupinus L. in Podillya are presented. The analysis of the species composition of the genus Lupinus was carried out and the prospects of their use for landscaping of various objects of Podillya area were determined. In order to differentiate plants in accordance with the scope of their possible use, the morphometric indices of the most promising species of this genus are given. The genus Lupinus comprises about 200 species growing in North America and the Mediterranean, being Perennial rhizome herbaceous plants, rarely half shrubs. We studied the biomorphological features of 11 species of the genus Lupinus (L. cosentinii Guss., $L$. pilosus, L. athlanticus, L. digitatus, L. hispanicus, L. princei, L. albicaulis Douglas, L. arboreus Sims, L. perennis L., L. nootkatensis Donn ex Sims.) and determination of the prospects of their cultivation in Podillya. Taking into account the high decorative qualities of these species and the wide possibilities of their application, these plants are of great interest to the gardening of our country and to replenish the range of flower and ornamental crops. We defined natural features of the genus Lupinus, flexibility to change their lifeform, high quality at a set of attributes that define their data characterizing decorative plants as a source for introductions and enriching the range of ornamental crops in Ukraine. From the practical point of view, all investigated species are of interest as potentially valuable objects for enriching the range of ornamental plants in Ukraine and are promising for improving the condition of parks, gardens, gardens in Podillya. The enrichment of the species diversity of ornamental cultures introduced by the species of Lupine, the expansion of options for simple and complex garden compositions with their participation, more even distribution within the settlements, will significantly approximate the design of the inhabited cities of Ukraine to the level of the best world standards.

Keywords: introduction; lupine; morphometric indices; natural range; biomorphological features. 